\title{
Vegetation of Ranikot Fort Area, a Historical Heritage of Sindh, Pakistan
}

\author{
Nabila Shah Jilani, Syeda Saleha Tahir, Muhammad Tahir Rajput \\ Institute of Plant Sciences, University of Sindh, Sindh, Pakistan \\ Email: nabila jilani@hotmail.com, jilani.nabila@gmail.com
}

Received 5 May 2014; revised 4 June 2014; accepted 22 June 2014

Copyright (C) 2014 by authors and Scientific Research Publishing Inc.

This work is licensed under the Creative Commons Attribution International License (CC BY).

http://creativecommons.org/licenses/by/4.0/

cC) (7) Open Access

\begin{abstract}
The investigation on the vegetation and flora of the Ranikot Fort area was undertaken during 2009-2013. Ranikot Fort Area is a historical heritage of Sindh. So far there has been no publication on vegetation of this important historic site. 89 plant species belonging to 69 genera and 32 families are identified which include monocot, dicots and pteridophytes. This contribution provides information on plant biodiversity of Ranikot, a natural heritage of Sindh, Pakistan.
\end{abstract}

\section{Keywords}

\section{Diversity, Ranikot Fort, Families, Species}

\section{Introduction}

Ranikot is a talismanic wonder of Sindh, which is visible about $5 \mathrm{~km}$ way over the hills. Every structure in the Ranikot has its own uniqueness and beauty. The investigation on the vegetation of Ranikot Fort was undertaken to document the plant wealth found in an important historical site area. So far there is no account on the vegetation of this area. The origin of Ranikot Fort is controversial but archaeologists and historians generally believe that it was constructed around 500 BC which was later on renovated by Talpurs, around 1819 AD. A large number of fossil wood and snail shell are found inside and outside the Ranikot Fort. Inside the fort, a fresh water spring is also present. The water of the spring is used for cultivation by the people living in the surroundings of the fort. The site area under investigation is also a good fossiliferous locality. Many fossil woods including monocot, dicot and gymnosperms were identified by many workers e.g. Ref: [1] and [2]. At the higher elevation the stones are mostly bigger in size and their size becomes smaller and smaller with the decrease in the elevation. In the valleys their size approaches to almost small clay particles.

\section{Site Area}

Ranikot Fort is located at $25^{\circ} 45^{\prime} \mathrm{N}-26^{\circ} 00^{\prime} \mathrm{N}$, long $67^{\circ} 45^{\prime} \mathrm{E}-68^{\circ} 00^{\prime} \mathrm{E}$ about $30 \mathrm{~km}$ south west of Sann Railway 
Station, $109 \mathrm{~km}$ from Jamshoro City of Sindh, Pakistan, $120 \mathrm{~km}$ from Dadu, and $124 \mathrm{~km}$ from Hyderabad. The circumference of the fort is about $30 \mathrm{~km}$, having walls constructed on about $8 \mathrm{~km}$ (personal com. Mr. Muhammad Siddiq Gabol, a guide of the Ranikot Fort area). At present the Indus River is about 18 miles away from the Fort. The study area is located at about 1480 feet above sea level. The site area comes under Khirther Range which falls under the Sahara-Sindhian region, Ref: [3]. The mean annual rainfall for Ranikot Fort Area is about 6 - 7 inches.

\section{Materials and Methods}

Survey and field collection of plants was carried out during September-October and February-March, 2009 to 2013. Herbarium sheets of the collected material were made following the standard techniques and were deposited in Sindh University Herbarium, at Jamshoro.

Most of the specimens collected from the site area were identified with the help of taxonomic key, description and illustrations provided in the flora of Pakistan. Ref: [3]-[9]. Every species is provided with a brief scientific description covering important taxonomic attributes, have been alphabetically arranged along with its family.

Vegetation of Ranikot Fort Area:

\begin{tabular}{ll}
\hline Family & Botanical name \\
\hline Barleria hochstetteri (Nees) \\
Acanthaceae Juss \\
Blepharis sindica (stock ex Anders) \\
Justica heterocarps (Anders.) \\
Cäboaceae Rudolphi. \\
Exell.
\end{tabular}

Zaleya pentandra (L.) Jeffrey

Achyranthes aspera Linn.

Aerva javanica (Burm f.) Jess Ex-Schult.

Amaranthaceae Juss.

Amaranthus viridis Linn

Celosia orgentea Linn.

\section{Description}

A small woody spineless shrub, coverd with soft hairs. Leaves oblong with appressed silky hair. Flower usually pinkish-white with few dark streaks. Fruit capsule.

A small prostrate erect dichotomously branched spiny herb. Leaves in whorls, liner-oblong with spiny bracts. Inflorescence a strobilute spike. Flowers mauve. Fruit capsule, ellipsoid. Vern. Assad/Bhangari.

A small herb with glandular hairs. Stem angular. Leaves ovate or ovate-lanceolate, entire. Flowers very small, pinkish, fruit dimorphic, capsule.

Fleshy, prostrate to semi-errect \pm radish herb. Leaves elliptic-ovate to obovate, cartilegenous, grayish-green. Inflorescence cyme. Flower dark pink. Seed strophiolate, compressed, black, glossy.

Prostrate herbs. leaves oblong, obovate with sheathing base. Flowers solitary, white to pale pink. Seed black, rugose.

Small herbs, erect to semi-prostrate. Stem 4-angled. Leaves oblong-elliplical or oval acute. Flower in terminal spikes, white to pale green or red or purple. Fruit capsule. Vern. Path Kanda.

White woody, deselytomentose herb. Stem much branched, leaves alternate, linear to linear lanceolate. Inflorescence of sessile spikes. Flower diocious, male flowers smaller, perianth colorless. Fruit capsules. Seed round, brown-black, glossy. Vern Booh.

Small green herbs, found near water sources. Leaves glabulour, ovate-deploid to rhomboid. Inflorescence panicle. Flowers small, male and female intermixed, perianth pale-green. Fruit capsule of irregular shape, seed brown-black. Vern. chilgah.

An erect much branched herb. Leaves linear, oblanceolate, acute, entire, leaf axils often with small branches. Inflorescence spike. Flower small, pale green. Fruit capsule, globular. Seed black, glossy. Vern Lular.

Dominant and common on all places, small evergreen shrub, leaves linear-lanceolate or elliplical to oblanceolate, becoming yellowish after maturation, sessile, entire, tapening on both ends. Flowers white, with little fragrant. Fruit follicles. Seeds brown small with short wings. Vern sainwar, sahaer, shanbor. 


\section{Continued}

Calotripis procera (Ait) Ait. f.

Leptadenia pyrotechnica (Forssk) Dene.

\section{Asclepiadaceae R. Br.}

Oystelma esculentum (Linn.f) R. Br.

Pergularia daemia (forssk.) Chiov.

Periploca aphylla Dcne.

Bignoniaceae Juss.

Tecomella undulata (Roxb) Seeman.

A small to a big shrub, much branched, have milky latex. Leaves thick lathery, broadly ovate or ovate oblong, entire, base cordate, acute. Inflorescence, umbelloid cyme. Flowers pinkish to purplish whithish outside, purplish inside, pedicelate, corolla thick, fleshy. Fruit recurved. Seeds flat, comose. Vern. Ak.

Erect much branched shrub, branches slender green. Leaves mostly not present when present on young stem are linear or linear, lanceolate. Flower yellow star like, corolla funnel-shaped. Inflorescence, small umbellate \pm , Fruit long follicles, terete. Vern. Mandi Khip.

A climber or twining herb with milky latex. Leaves opposite linear or linear lanceolate, acute. Inflorescence. Flowers white or pale rose or attractive lilac, usually in cluster. Fruit follicles. Vern. Naro.

A tomentose twining herb with milky latex. leaves heart shaped or ovate leafbase, cordate acute. Inflorescence cyme. Flowers yellowish-green or dull white, fruit prickly borne in pairs, lanceolate beaked.

Erect lefless shrub, similar to leptadeniapyrotrachnia but branches are shorter, young leaves, ovate oblong. Inflorescence cyme. Flowers purplish-white, white or greenish white with purple center. Fruit follicles. Seed compressed, oblong, comose.

A small tree with very beautiful yellow orange flowers, very attractive tree. Leaves opposite, entire, oblong-elliptical to linear-oblong, magin undulate. Inflorescence, raceme having 2 - 7 flowers. Flowers large, orange red. Fruit capsule, linear. Seed slightly curved, winged.

Vern. Lohiro.

Woody shrubs or tree. Leaves oblong-ellaptical, oblanceolate, entire. Flowers white. Fruit drup, bright orange, edible. Vern. Liar, Lyar.

A hairy herb, leaves oblong-ovate, densely hairy, inflorescence spreading with uniserial fruit nut lets, flowers white, borne on elongate spikes. Vern. Khorsum.

Small herb to shrub, leaves linear-lanceolate, undulate. Inflorescence terminal with uniseriate. Flowers white. Fruit sub-globose, 4-lobed nutlets. There is great variation in the size of plant and degree of pubescence. Vern. Kharsun.

Erect hairy herb. Branches green or greynish-green, leaves

Heliotropium europium L. elliplical-ovate. Inflorescence terminal with closely arranged on coiled cymes. Flowers white. Fruit nutlets. Vern. Khursum.

Heliotropium ophioglossum Stocks ex. Herbs to small shrubs, hairy, leaves elliplical to elliptic-lanceolate.
Flowers white uniseriate on branched coil stalks. Fruit brown, lobed Boiss. nutlets. Vern. Kharsuno.

Tall shrubs to small tree. Stem woody, brahces covered with papery bark. Leaves alternate, compound, leaflet oblong-orbicular or obovate, entire.

Commiphora stocksiana (Engl.) Engl. Flowers small, pale pink petal 4. Fruit marked with lines, semiglobose. Vern. Bhayi.

Small shrubs; branches aromatic with papery shiny bark. Leaves alternate usually 1-3 foliate, leaflet obovate, serriate. Flowers usually red or pinkish red. Fruit red rarely orange-yellow with 4-large longitudational lines. Vern. Gugar.

Very common, small erect herbs. Leaves compound, with 5 - 8 leaflets. Leaflets linear-lanceolate. Flowers yellowish-white arranged in axillary recemes. Fruit pod flat, thin, papery recurved, rounded at the end. Seed flattened, yellow, vern. Janglisana., Ghora Val.

Frequently distributed, small herb, pale green. Leaves compound with 3 - 7 pairs of leaflets. Inflorescences axillary receme. Flowers yellow. Fruit pod, thin, papery rounded on both ends. Seed dark brown. Vern. Senna, Dadhwal. 


\section{Continued}

Cadaba farinosa Forssk.

Capparis cartilaginea Decne

Capparis decidua (Fossk) Edgew.

Capparidaceae Juss.

Cleome brachycarpa Vahl ex DC. oblong, obovate or liner lanceolate. Flowers yellow, gynophors, Dhanar Khatori.

Cleome scaposa DC

Small erect herb with glandular hairs, leaves simple, ovate, sub-orbicular ovate-elliptical. Flowers yellow to pale white. Fruit capsule, liners. Seed, minute brown black. Vern. Waho.

Big herb with glandular hairs. Leaves compound 3 - 7 foliate, leafletobovate to Gynandropsis gynandra (L.) Briq elliptical. Flowers yellow white or pinkish. Androphore and gynophore present, Fruit capsule. Seed small, dark brown. Vern, hurhuria, karalia.

A woody shrub with week stem, usually associated with other plants for Maecrua arenaria (DC.) Hook f. support. Leaves simple, oblong-ovate. Flowers arranged in dense corymbose \& Thoms racemes, white to greenish white. Fruit cylindrical, brown. Seeds, small tuberculate.
Salsola imbricata Forssk.

Chenopodiaceae Vent.

Asteraceae Dum.

Convolvulaceae Juss.

Convolvulus glomeratus Choisy

Suaeda fruticosa Forrisk ex. J.F Gmelin.

Conyza canadensis (L.) Cronquist

Echinops echinatus Roxb.

Eclipta alba (L.) Hassk.

Launaea procumbens (Roxb)

Ramayya \& Rajgopal.

Vernonia cinerascens Sch. Bip.

Convolvulus arvensis L. ovate-oblong, liner-oblong, Sagittate to hastate, acute. Flowers pale pink to bluish to pink. Pale pink to lilac with dark purple bands. Fruit capsule globose. Seed 4 per capsule, dark brown, tuberculate.

A perennial twining herb with delicate weak stem. Densely tomentose with appressed hairs. Densely interlaced. Leaves ovate or oblong-lanceolate, acute. Flowers pink-white or purple 4 - 10 in axillary heads. Fruit capsule with 2 - 4 seeds. Seeds brown.

Very common prostrate herb. Profusely branched, densely tomentose. Leaves

Convolvulus prostrates Forssk. sessile, linear-oblong or oblanceolate, acute obtuse, fruit capsule with 2 - 4 seeds. Seeds blackish-brown hairy.

Common on saline soil. A small erect herb, woody at the base, tomentose.

Cressa cretica L.
Leaves sessile, ovate-lanceolate to ovate. Flowers white, small. Fruit ovoid with 1 seed. Seed glossy, brownish black. 


\section{Continued}

\section{Cucurbitaceae Juss. Cucumis prophetarum L.}

Euphorbiaceae Juss. Euphorbia hirta L.

Gentianaceae Juss.

Enicostemma hyssopifolium (Wild) verdoon

Acacia nilotica (Linn.) delile.

Mimosaceae R. Br.

Fabaceae Lindl.

Prosopis cineraria (L.) Bruce.

Alhagi maurorum Medic.

Indigofera cordifolia Hyne ex Roth.

Portulacaceae Juss.

Resedaceae S.F. Gray. Ochradenus baccatus Delile

Rhamnaceae Juss.

SalvadoraceaeLindl.

Solanaceae Juss

Indigofera oblongifolia Forsk.

Melilotus indica (L.) All

Portulaca oleracea L.

Ziziphus nummularia (Brum) W. \& Arn.

Salvadora oleoides Decne.

Salvadora persica L.

Lycium edgeworhii Dunal

Solanum surattense Burn.

A common small trailing or prostrate herb. Leaves ovate-orbicular

Cordate-truncate at the base. Tendril, simple, short. Flower yellow-white, male

flower 2 - 3 together, female flower mostly solitary. Fruit yellow, prickly-ovoid, echlinate. Seed \pm oblong, ashy-grey. Vern. Kirmit or Khorchvit.

Small herb, common in cultivated areas in onion fields. Leaves rhombic ovate. Flowers in axillary clusters, forming cyathia. Fruit trigonous.

Small erect to sub-erect herb. Leaves linear or linear-oblong, simple, opposite, sessile, entire. Flowers solitary or 2 - 6 together, white. Fruit capsule, many seeded. Seed minute globose, brown, reticulate.

A medium sized tree with fissured brownish-black. bark stipule spinescent Linear-oblong. Leaves compound with petioler gland, leaflet 7 - 25 pairs. Inflorescnence head. Flowers in spikes, yellowish-white or bright-yellow. Fruit pod, indehiscent, straight or curved. Seed black-brown \pm orbicular. Vern. Bhaber, Kaker.

A large shrub to tree. Branches with curved prickles. Leaves altenate, compound, bipinnate, leaflets 7 - 12 pairs, oblong, oblique. Flowers creamy white, anther lapped with glands. Fruit pod, slander. Seeds oblong, compressed. Vern. Kandi.

Spiny herb to small shrub. Leaves simple, oblong-eliptical, obovate, entire, Flowers Pinkish-Red. Fruit 1 - 9 Seeded legume. Vern. Kandeero, Janasa.

A small erect to prostrate herb. Leaves simple, thick, broadly-ovate or cordate. Flowers bright red, 4 - 8 in dense cluster. Fruit oblong, densely pubescent 2-seeded. Vern. Mohari.

Small erect shrub with bark purplish. Mostly 3 - 5 foliate leaflet, oblanceolate or elliptical-oblong. Flowers red, Fruit pod, curved, reddish. 6 - 8 seeded. Vernacular: Jhil.

Erect herb. Leaves trifoliate leaflet oblong or lanceolate, dentate. Flowers yellow. Fruit 1-seeded with prominent veins. Vern. Sinjhi.

Prostrate to erect. Fleshy or succulent herb. Leavs alternate to sub-opposite. crowded near the flower, spathulate or obovate-oblong. Fruit capsule with many seeds. Seed small renifrom. Glossy, black-aligned tuberculate. Vern. Lunk.

Slender, small bush, branches green. Leaves linear, acute. Flowers yellowish-white or yellowish green on long receme. Fruit berry, white. Seed brown, reniform.

Very common, small bushy much branched shrub. Branches Divaricoting with spines in unequal pairs. Spine are straight. Other recurved. Leave thick, orbicular or ovate-orbicular. Flowers cream white inconspicuous. Fruit drupe edible, round, brown or redish brown when ripe. 2 celled. Seed 2, brown \pm flat. Vern. Beri or Ber.

A shrub to small tree, branches stiff, leaves linear, linear-lanceolate, acute.Flowers greenish-white, 4 merous. Fruit drupe, globose, pinkish-yellow at maturation. Seed 1, brown, Vern. Khabbar.

Big shrub to tree, evergreen, profusely branched. Leaves broad, ovate-elliptical, sub flashy, petiolate. Flowers yellowish-green, 4-mesois. Fruit drup white or purple at maturation. globose. Seed 1-grayish-brown.

A small spiny shrub. Branches ash-gray, ending in spines. Leaves oblong-elliptical, obtuse to acute. Flowers white. Fruit berry, red globose. Seed brown reniform. Vern. Garathi.

A prickly-prostrate herb. Prickles yellow. Leave prickly Elliptic-oblong, deeply lobed. Dark green above. Flowers bluish to purple, calyx prickly. Fruit yellow, berry, globose. Seeds many, discoid, smooth to faintly reliculate. Vern. Katari or Dadhi.

Common small grayish green herb, tomentose. Leaves obovate,

elliptical-lanceolate, thicker or \pm lathery. Pale-green. Fruit berry, red. enclosed in inflated calyx. Seed many. brown, reniform. smooth to reticulate. Vern.

Paneerband.

Herbaceous shrub, grayish green, tomentose, Leaves broadly ovate or acute

Withania somnifera (L.) Dunal. entire. Flowers greenish or yellowish. Fruit red berry, globose. Seed many light brown, smooth to reliculate. Sub pyriform to reniform. 


\section{Continued}

Tamarix alii Qaiser

Tamaricaceae Link.
A woody shrub with reddish brown bark. Leaves scale like, vaginate with a short spine. Flowers pink in terminal clustera. Vern. Lai or Lawi.

Tall woody, shrub to small tree with reddish bark, plant dioecious. Leaves Tamarix dioica Roxb. ex. Roth. vaginate abruptly acuminate. Flowers male and female and borne on separate plants. Flowers purplish in dense spikes. Vern. Lawi or Lai.

Corchorus depressus (L.) Stocks.

Tiliaceae Juss.

Corchorus tridens L.

Verbenaceae Joumest-hil.
Phyla nodiflora (L.) Greene
A common small mat forming, much branched, woody herb. Leaves crenate, elliplical to broad elliptical. Flowers yellow. Fruit capsule, oblong, cylindrical, straight or slightly curved. Seeds many grey-black, \pm triangular. Vern. Mundiari or Mundhiri or Bhophali.

Prostrate to erect herb. Leaf simple, oblong-lanceolate. Linear-lanceolate, sometimes elliptic ovate. Flowers axillary yellow. Fruit capsule. 1 - 3 together, cylindrical, seed black angular, obliquely truncate at ends. Vern. Bhaindri or Kawavatorai.

Prostrate herb forming mat-like structure on the ground, rooting at nodes. Leaves simple, oblanceolate, obovate-spathulate, serate. Flower tiny pink or pinkish-white in compact spikes. like in cones. Fruit ovate, enclosed in persistent calyx. Seed 1 in pyrenes.

\section{Monocots}

\begin{tabular}{ll}
\hline Family & Botanical name \\
\hline & Cyperus arenarius Retz. \\
Cyperaceae Juss. & Cyprus rotundus L. \\
& Schoenoplectus littoralis (Schrad) Palla
\end{tabular}

\section{Description}

Small erect herb with long underground creeping rhizome. Spike in terminal clusters.

Small erect herb. Leaf at the base of the flowering stalk. Growing near water chanals. Vern. Kabah, Motha, Chia, Dela etc.

A tall erect rhizomatous herb. Common in shallow running water around the streams. Spikes borne on terminal portion of stiff stalk.

A clump forming species with long stiff branches. Leaves present near the base only, cylindric, sharply tipped. Flowers in cluster in terminal portion. Fruit capsule, ovoid-trigonous. Seed many, oblong-elliplical, \pm brownish. Vern. Chab.

Erect green herb. Common in cultivated onion crops. Leaves few borne at the base, linear. Flowers white in terminal receme. Fruit capsule. Seed black.

Small prostate to erect rhizomatous perennial herb. Leaf-blade, narrow, stiff, pungent. Flowers in spikelets, densely crowded in compact, globosepenicle, spikelets 4 - 8 flowered. Usually forming patches on sandy to saline soils, especially around marshy places. A common species in arid places.

Very common grass in Ranikot Fort area. It has 4 to 5 species in the field morphologically difficult to identify. Vern. Lumb grass.

Brachiaria eruciformis (J. E. Smith) Griseb

\section{Cenchrus setigerus Vahl}

Poaceae Barnhart.

Chrysopogon aucheri (Boiss) stapf.

Cymbopogon jwarancusa (Jones)

Schult.

A common loosely tufted erect herb. Leaf blade, linear to narrowlanceolate. Inflorescence of 3 - 12 racemes. Spikelet arranged in raceme.

Small erect herb. Leaf blade, linear, spikelets with spines, brown to black. Vern. Dhaman.

Very common fodder gross. Leaf blade, long upto $25 \mathrm{~cm}$. Clump forming erect tall gross upto $65 \mathrm{~cm}$ high. Leaf sheath silky hairy, Spikelets in spreading panicles. A common deseart species on rocky slopes.

An erect tall gross with fragrant roots. Leaves flat, spikelets in racemes, densely hairy, slightly lemon scented gross. Vern. Poi.

Dactyloctenium aristatum Link. Spreading herb. Prostrate to erect, Spikes compact, usually 6. Vern. Sanwri.

Geniculately tall herb, with green leaves. Flowers in racemes, 2 - 12 digitate. Spikelets arranged along entire length. Common on moist shady places.

Tufted annual grass. Leaves folded, spikes slender. A common fodder gross in moist places. 


\section{Continued}

Pennisetum orientale L.C. Rich.

Typhaceae Juss. Typha species
A perennial grass upto $45 \mathrm{~cm}$ tall. Spikes surrounded with soft bristles.

It is very common on wetland, locally used for thatching roofs and making floor mats. A tall stout grass like monoecious herb with thick rhizomes. Leaves alternate, leaf at the base blade-linear, parallel-veined, leaf sheathing present. Flowers arranged in densely compat spike, upper portion of spike which is \pm yellow have male flowers; lower, bigger and cylindrical brown portion contains female flowers. Fruit achene, surrounded by hairs. Seeds small. This has 3 - 4 species but difficult to identify.

\section{Pteridophyta (S.F. Gray) Gandich.}

\begin{tabular}{lll}
\hline Family & Botanical Name & Description \\
\hline Pteridaceae & Adiantum capilus veneris L. & $\begin{array}{l}\text { Small erect fern. Round lufted 1-3 pinnate. Rachis shiny, } \\
\text { redish-black or brown. Found in moist shady place. } \\
\text { Common along water channels. } \\
\end{array}$ \\
& Vern. Persaushian. \\
\hline
\end{tabular}

\section{Results and Discussion}

The field survey reveals the presence of twenty-nine angiospermic families including five monocotyledons and twenty four dicotyledons. Besides these, pteridophytic species of Adiantum has also been reported. Tamerix and Salvadora species are dominant in depressions. Rizastricta is very common on both side of the road leading to Ranikot Fort from Sunn.

The great diversity of Ranikot's natural environment includes about $30 \mathrm{~km}$ area. The species composition and vegetation cover are profoundly affected by the Ranikot rocks and their derived soil. The plants growing on the top hills have mostly exposed roots.

Some of the species are directly threatened by human activates which includes the construction of roads, bridges overgrazing by animals and had great effect on biota. Majority of the species reported in Mohan-JoDaro are present in present study area.

\section{Conclusion}

During this research it has been observed that the vegetation of this important historical fort, which is claimed to be the largest fort of the world, is totally neglected. No research has been done in past. The current condition of the vegetation is critical. During survey it was observed that members of the Poaceae family were found dominating among all plant families throughout the year. Majority of the plants are herbs that belong to Poaceae family. It is also reported, that there are only a few trees present in Ranikot Fort area e.g. Salvadora oleoides, zizphusjujube, Acacia nilotica. In the beginning when I first visited this area for collection, Acacia tree was dominating species of the area amongst all tree species. Now, it has become endangered as just a few trees are surviving with poor condition. They are being chopped by the local people for different purposes like fuel, shelter; they use Acacia trunk and branches for making house boundary. They remove bark to make raw wine, which results in the disappearance of Acacia from Ranikot Fort area. The other disappearing species is Commiphora wightii Vern. Gugur. Only a few trees of Gugur are left, which are in very poor conditions as well, this will lead to total disappearance of the plant from this particular area.

\section{References}

[1] Ahmed, B., Rajput, M.T.M. and Khan, K.M. (1989) Laurinoxylon ellipticum sp. nov., a New Petrified Taxon of Lauraceae from Tertiary Deposits of Sindh, Pakistan. Pakistan Journal of Botany, 40.

[2] Rajput, M.T.M. and Khan, K.M. (1984) Araucarioxylan sp. nov., a New Species of Gymnosperm Wood from Manchhar Formation. Pakistan Journal of Botany, 16, 53-76.

[3] Ali, S.I. and Qaiser, M. (1986) A Phytogeographic Analysis of the Phanerogams of Pakistan and Kashmir. Proceedings of the Royal Society of Edinburgh, 89B, 89-101.

[4] Akhter, R. (2003) A Plant Guide to National Park Khirthar and Adjoining Areas. Premier-Kufpec, Pakistan B.V. 1. 
[5] Ali, S.I. and Qaiser, M. (1993-2008) Flora of Pakistan-Karachi.

[6] Ali, S.I. and Nasir, Y.J. (1989-1993) Flora of Pakistan-Islamabad, Karachi.

[7] Bhnadari, M.M. (1975) Flora of Indian Desert. Scientific Publishers, Jodhpur.

[8] Jafri, S.M.H. (1966) The Flora of Karachi-The Book Corporation. Karachi, Pakistan.

[9] Nasir, E. and Ali, S.I. (1970-1989) Flora of Pakistan. 
Scientific Research Publishing (SCIRP) is one of the largest Open Access journal publishers. It is currently publishing more than 200 open access, online, peer-reviewed journals covering a wide range of academic disciplines. SCIRP serves the worldwide academic communities and contributes to the progress and application of science with its publication.

Other selected journals from SCIRP are listed as below. Submit your manuscript to us via either submit@scirp.org or Online Submission Portal.
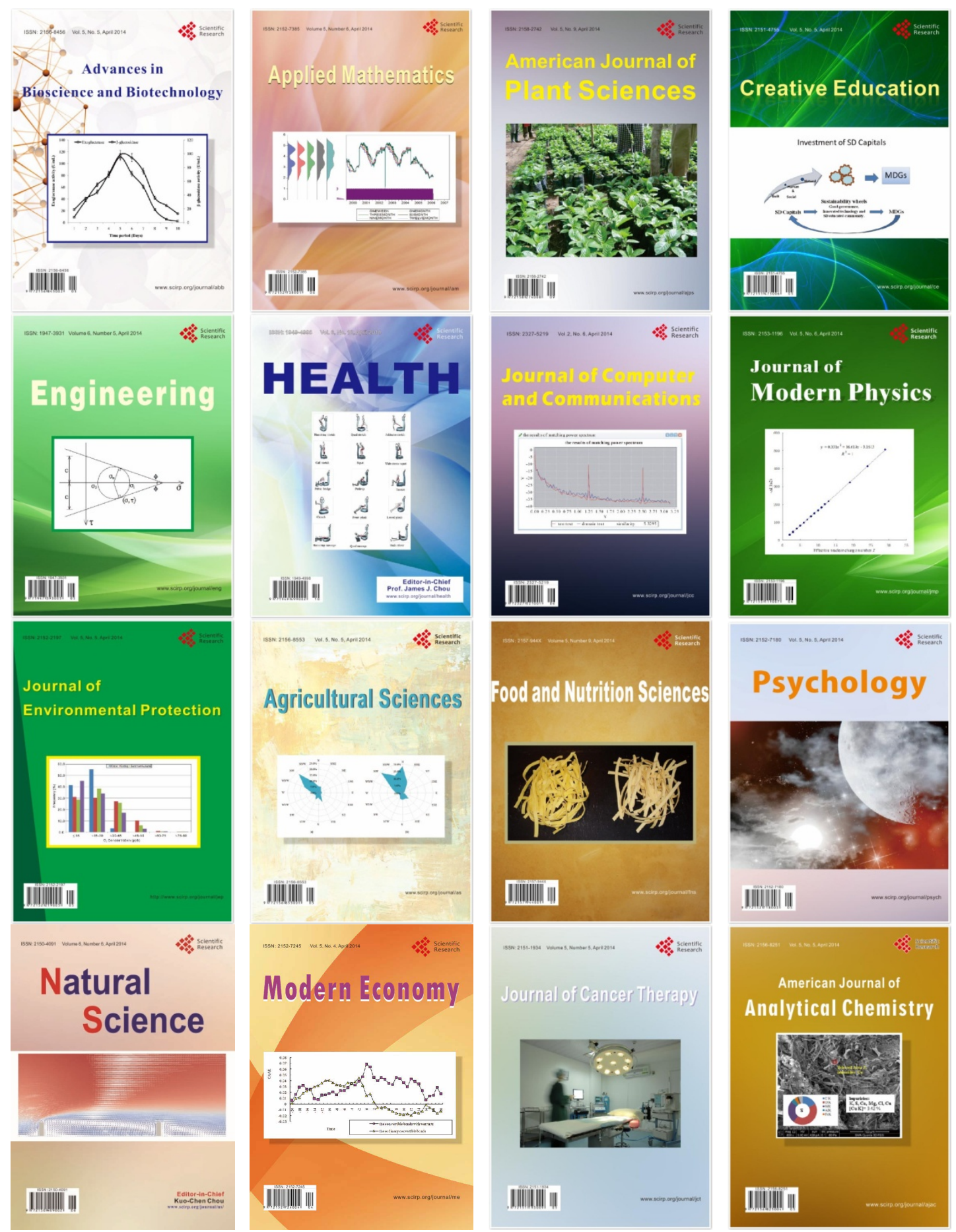